\title{
外装用高耐久性土壁調超軽量仕上げ材料の開発 \\ DEVELOPMENT OF HIGHLY DURABLE MUD WALL-STYLE SUPERLIGHTWEIGHT FINISH MATERIALS FOR EXTERIOR FINISHES
}

\author{
篠崎征夫*
}

Yukuo SHINOZAKI

\begin{abstract}
Recently, mud wall-style diatomaceus earth finish materials have been used for exterior finish work for buildings. However, the finish materials are not preferable as the exterior finishes exposed to severe environmental conditions such as cold regions, because they have originally been developed for interior finish work. In this paper, highly durable mud wall-style superlightweight finish materials using superlightweight polymer-modified motars are developed for exterior finish work. Mud wall-style finish materials are experimentally prepared using carbon fiber-reinforced polymer-modified mortars añd a superlightweight aggegate, and tested for strength, density, water absorption, thermal conductivity, adhesion, adhesion durability and freeze-thaw durability. From the test results, their excellent durability is confirmed.
\end{abstract}

Keywords : Exterior finishes, Mud wall-style, High durability, Superlightweight polymer-modified motar, Microballoon, Carbon fiber reinforcement

外装伐ヒ:゙゙、土壁調、高耐久性、超軽量ポリマーセメントモルタル、マイクロバルーン、炭素䋐維補強

\section{1. はじめに}

近年、環境共生材料などの名のもとに、建物の外装材として土壁 調のけいそう土仩 は:げ材料が盛んに採为されるようになってきた。 しかしながら、これら材料は、もともとけいそう土の存する吸・放 湿性や脱手性能などに注日した内装材料として開発されたものであ るため、睘境条件の南しい外装、中でも寒冷地などにおける使斗に あたっては、その耐久性が奬念される。このようなことから、著者 は、これまで開発してきた超訤量ポリマーセメントモルタルをベー スにして、耐久性に優れた土壁誥の外装仩:ば材料を開発した。本 材料は、無機と有機のマイクロバルーンを軽量骨材とし、炭素紹維 を補強材として为いたポリマーとセメントの複合休で、これらのバ ランスよい材料满成によって、いままでにない高耐久性を肾現して いる。

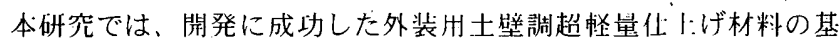
本物性の他に、温冷繰这し試験（熱サイクル試験）、谏結础解試験な どの促進劣化試験及び屋外暴露試験による耐久性評価試験を尖施し、 その耐久性が極めて優れていることを明らかにしている。

\section{2. 外装用土壁調超軽量仕上げ材料の概要}

本材料は、マイクロバルーン(超狶星微小中空発泡休)、炭素䋐維、 水浴性樹脂、セメント湝和为ポリマーディスパージョンなどを主啮 成材料とする半液怵状のペースト材料と、セメント、柽量骨材、喠々 の種不やけいそう土、顔料などをバランス良く組み合わせたモル夕 ル材料である。本材料を壁に塗り付け後に、かき落しなどの伝統的 な技法(1:法)を加えることによって土壁䚺の仕はげを行うもので、 これら材料や、法の縕合わせによって、様々なテクスチャーが表垷

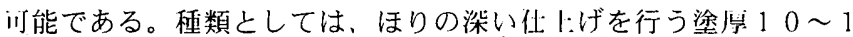

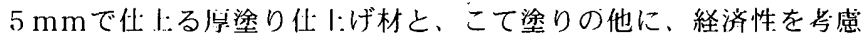

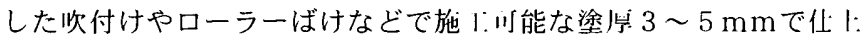
る薄塗り仕:ば材の 2 種類から構成される。

\section{3. 使用村料}

\section{1 ペースト村料}

ペースト材料は、マイクロバルーン(ポリ塭化ビニリデン発沧体、

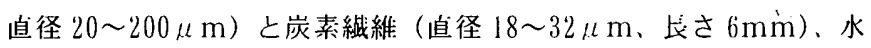
浴性樹脂（メチルセルロース）、ポリマーディスパージョン（エチレ ン酢酸ビニルエマルション) などをあらかじめ練り混ぜて粡成され る。表ー1には、ペースト材料の紞成を示す。 
表一 1 ペースト材料の組成

\begin{tabular}{|c|c|}
\hline 構成材料 & 配合比（\%) \\
\hline 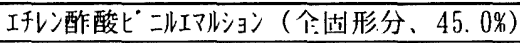 & 10.23 \\
\hline 炭素䋐維 & 1.36 \\
\hline 迥师盈化 & 26.65 \\
\hline その他 & 0.77 \\
\hline 水道水 & 60.99 \\
\hline
\end{tabular}

\section{2 セメント}

セメントとしては、ロ色ポルトランドセメントを州いた。表一 2 には、色ポルトランドセメントの物性を、また、埊ー 3 には、そ の化学成分を示す。

表 -2 白色ポルトランドセメントの物性

\begin{tabular}{|c|c|c|c|c|c|c|c|c|}
\hline \multirow{2}{*}{$\begin{array}{l}\text { 密度 } \\
\left(\mathrm{g} / \mathrm{cm}^{3}\right)\end{array}$} & \multirow{2}{*}{ 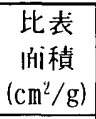 } & \multicolumn{3}{|c|}{ 凝絬 } & \multirow[b]{2}{*}{ 公定性 } & \multicolumn{3}{|c|}{ 厈維強さ $\left(\mathrm{N} / \mathrm{mm}^{2}\right)$} \\
\hline & & $\begin{array}{c}\text { 水㫫 } \\
(\text { (\%) }\end{array}$ & $\begin{array}{c}\text { 始結 } \\
\text { (h-min) }\end{array}$ & $\begin{array}{c}\text { 終結 } \\
\text { (h-min) } \\
\end{array}$ & & $3 d$ & $7 d$ & $28 \mathrm{~d}$ \\
\hline 3.05 & 3660 & 28.6 & $2-29$ & $3-34$ & 良 & 33.8 & 47.5 & 64. 7 \\
\hline
\end{tabular}

表 -3 白色ポルトランドセメントの化学成分

\begin{tabular}{|c|c|c|c|c|c|}
\hline \multicolumn{6}{|c|}{ 化学:成分 (\%) } \\
\hline $\mathrm{MgO}$ & $\mathrm{SO}_{3}$ & ig. loss & 䍱沏! & $\mathrm{C}^{-}$ & $\begin{array}{c}\text { 八㶤- } \\
\text { 向色度 }\end{array}$ \\
\hline 0.68 & 2. 77 & 2. 85 & 0.25 & 0.004 & 92.5 \\
\hline
\end{tabular}

\section{3 軽量角材及び種石}

㹩荲骨材としては、シラスバルーンを州いた。表ー4には、シラ スバルーンの物理的吽質及び化学成分を示す。また、仩は:げ材の種

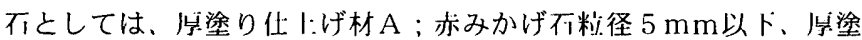

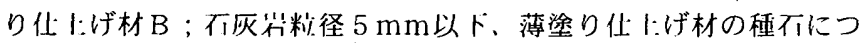
いてはいずれも寒水不粉径 $1.5 \mathrm{~mm}$ 使用した。

表ー4 シラスバルーンの性質

\begin{tabular}{|c|c|c|c|c|c|c|c|}
\hline $\begin{array}{c}\text { かさ密度 } \\
\left(\mathrm{g} / \mathrm{cm}^{3}\right)\end{array}$ & $\begin{array}{c}\text { 平均粘経 } \\
(\mu \mathrm{m})\end{array}$ & \multicolumn{6}{|c|}{ 化学成分 $(\%)$} \\
\cline { 4 - 8 } & $\mathrm{Si}_{2}$ & $\mathrm{Al}_{2} 0_{3}$ & $\mathrm{Fe}_{2} 0_{3}$ & $\mathrm{Na}_{2} 0$ & $\mathrm{~K}_{2} 0$ & ig. IOSS \\
\hline $\begin{array}{c}0.14 \\
\sim 0.17\end{array}$ & 80 & $\begin{array}{c}75 \\
\sim 77\end{array}$ & $\begin{array}{c}12 \\
\sim 14\end{array}$ & $1 \sim 2$ & $3 \sim 4$ & $2 \sim 4$ & $2 \sim 5$ \\
\hline
\end{tabular}

\section{4 はっ水舦}

はっ水剤としては、塗布タイプの表ー 5 にホすシラン系化合物を 州いた。

表一 5 はっ水剂の化学組成及び性質

\begin{tabular}{|c|c|c|c|}
\hline 化学組成 & 外観 & 粘度 $\left(\mathrm{mPa}^{\mathrm{sP}} \mathrm{s}\right)$ & 密度 $\left(\mathrm{g} / \mathrm{cm}^{3}\right)$ \\
\hline シラン系化合物 & 無色透明液体 & 10 以ト & $0.84 \sim 0.86$ \\
\hline
\end{tabular}

\section{4. 試铪方法}

\section{1 試繁仕上げ材の略製}

表ー6に示す調合に従って、モルタル州ミキサーを州いて、あら かじめペースト材料とセメント及び㹩荲骨材を水を加えながら均一 になるまで約 2 min 練り芘ぜて後。種不を混入して更に約 1 min 練り 混ぜて試製仕:はげ材を調製した。
表ー6 試製仕上げ材の調合

\begin{tabular}{|c|c|c|c|c|c|c|}
\hline 試製仕:げ材の種類 & $\begin{array}{l}\Lambda^{\circ}-\text { 자 } \\
\text { 材料 } \\
(\mathrm{kg})\end{array}$ & $\begin{array}{l}\text { セxント } \\
(\mathrm{kg})\end{array}$ & $\begin{array}{l}\text { 船量 } \\
\text { 骨材 } \\
(\mathrm{kg})\end{array}$ & $\begin{array}{l}\text { 種不 } \\
(\mathrm{kg})\end{array}$ & $\begin{array}{c}\text { 水 } \\
(\mathrm{kg})\end{array}$ & $\begin{array}{l}\text { 単位, 容 } \\
\text { 積質量 } \\
(\mathrm{kg} / \mathrm{l})\end{array}$ \\
\hline $\begin{array}{c}\text { 崇塗り优 I:げ材 A } \\
\text { (外装师) }\end{array}$ & 11.0 & 14. 0 & 0.7 & 27. 0 & 3.9 & 1.21 \\
\hline 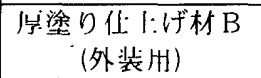 & 11.0 & 14. 0 & 0.7 & 21.0 & 3.8 & 1. 20 \\
\hline $\begin{array}{c}\text { 薄塗り仕 I:げ材 C } \\
\text { (外装出) }\end{array}$ & \multirow{2}{*}{11.0} & \multirow{2}{*}{ 14. 0} & \multirow{2}{*}{0.7} & \multirow{2}{*}{ 15. 0} & \multirow{2}{*}{3.8} & \multirow{2}{*}{1.25} \\
\hline $\begin{array}{c}\text { 薄塗り价: : げ材 C } \\
\text { (内装为) }\end{array}$ & & & & & & \\
\hline $\begin{array}{c}\text { 薄塗り仩 } 1: け ゙ \text { 材 D } \\
\text { (外装开) }\end{array}$ & \multirow{2}{*}{ 11. 0} & \multirow{2}{*}{ 14. 0} & \multirow{2}{*}{0.7} & \multirow{2}{*}{ 40. 0} & \multirow{2}{*}{5.8} & \multirow{2}{*}{ 1. 33} \\
\hline $\begin{array}{c}\text { 薄塗り位 I:げ材D } \\
\text { (内装开) }\end{array}$ & & & & & & \\
\hline
\end{tabular}

注）外装州；はっ水剤を塗布したもの

内装州；はっ水剂の塗布なし

\section{2 単位容糟賈量試験}

JIS A 11771 （ポリマーセメントモルタルの試験っ法）に準じ て、試製优、げ゙材の単位谷積質量を測定した。

\section{3 曲げ及び圧縮強さ試験}

JIS R 5201 (セメントの物理試験 法）に準じて、試製仕は: げ材の試験体（寸法、40×40×160 mm）を成形し、 $2 \mathrm{~d}$ 湿 空 $\left(20 \pm 2{ }^{\circ} \mathrm{C} 、 80 \%(\mathrm{RH})\right)$ 粪生後、脱型してから、26 d 乾燥 (20 $\left.202^{\circ} \mathrm{C} 、 65 \pm 5 \%(\mathrm{RH})\right)$ 盖生して、試験体を作製した。イ ンストロンク能試験機を州いて、クロスヘッド速度 $2 \mathrm{~mm} / \mathrm{min}$ で試 験体の山げ及び厈維強さ試験を行った。

\section{4 気乾密度及ひ吸水東試験}

4.3 と问様の力法で試験体（寸法、 $40 \times 40 \times 160 \mathrm{~mm}$ ）を 作製した。外装出については、作製した試験休に、はっ水剤を塗布 した。塗布は、はけを州いて塗布量 $200 \mathrm{~g} / \mathrm{m}^{2}$ 計堇しながら行 い、24h 乾燥後に試験に供した。これらの試験休については、JIS A 1171 (ポリマーセメントモルタルの試験力法)に準じて、4 $8 \mathrm{~h}$ 後の吸水率を測定した。また、比較として内装策（はっ水剤塗 布なし）についても间様の試験を行った。更に、吸水率試験前の試 験怵質量から父乾密度を算出した。

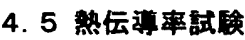

京都電子 : 業（株）製の迅速熱伝導率計 QTM- 500 を州いて、 4.3 と间様に作製した試験体の熱伝導率を测定した。

\section{6 接养強さ及ひ接着耐久性試殷}

被着休としてのコンクリートト地のモデルとして、JIS A 537 1 付质韋 2 (烧定) 舖装为平板に惯定するコンクリート平板(寸法、3 $00 \times 300 \times 60 \mathrm{~mm})$ を州い、その表的をワイヤブラシで清捽後、

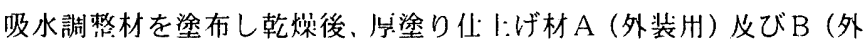
装开）；10 mm、薄塗り仕: I:げ材 C (外装用)； $5 \mathrm{~mm}$ 、薄塗り仩 I:げ材D（外装开）； $3 \mathrm{~mm}$ 塗り付けて試験体を作製し、28 d 乾燥 (20 $\left.202^{\circ} \mathrm{C} 、 65 \pm 5 \%(\mathrm{RH})\right)$ 峜生した。なお、外装为について 
は、4４４に示す间様のっ法ではっ水剂を塗布した。

また、薄塗り仩ト:げ材 C 及びDについては、外装开の他に、比較 として内装州（はっ水剂塗布なし）についても合わせて们様の片法 で検封した。

\section{1）標準時接着強さ試験}

$28 \mathrm{~d}$ 乾燥 $\left(20 \pm 2^{\circ} \mathrm{C} 、 65 \pm 5 \%(\mathrm{RH})\right)$ 金生した試験

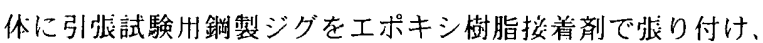
ジグの㸡辺をカッターでコンクリートト地板に達するまで切 巡みを入れた後、建研式引张試験機を开いて接着強さを測定 した。なお、試験怵数は 3 湖とした。

2）水中浸漬後の接着強さ試験

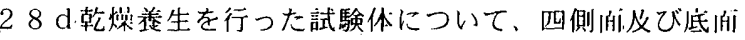
部をエポキシ樹脂でシールし、 $5 \mathrm{~d}$ 乾燥盖生した。その後、

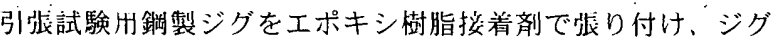
の凬巡をカッターでコンクリートト地板に達するまで切巡み を入れてから $48 \mathrm{~h}$ 水中浸漬を行い、水中から取り山した後 直ちに、1）と闹様のう法で挍着強さ（試験体数 3 個）を测 定した。

3）温冷繰返し試験(熱サイクル試験)後の接着強さ試験

表一, 6 に示す試製仕 は:げ材の中で、使州時に苛酷な環境条 件トに丞露されることが予想される岶塗り仕けげ材のA（外 装帅）についてだけ本試験を行った。4.6 と同様に作製し

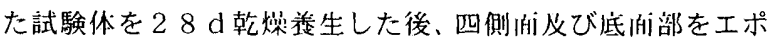
キシ樹脂でシールし、 $5 \mathrm{~d}$ 乾煐養生した。これらの試験体を 温冷繰这し試験機（熱サイクル試験機） $\left.{ }^{9}\right)$ に入れ、0、5 $0 、 100 、 150$ 及び 300 サイクル試験終了ごとに試験 体を取り山し、各サイクルごとの接着強さの変化を、 4.6 1 ) 標準時接着強さ試験乃法と阔様のち法で测定した。なお、 熱サイクルは $105 \mathrm{~min}$ で試験体の表消が空温から $700^{\circ} \mathrm{C} に$ 達するまでヒ一ターで加熱し、7 $0{ }^{\circ} \mathrm{C}$ に達したら水道水を散

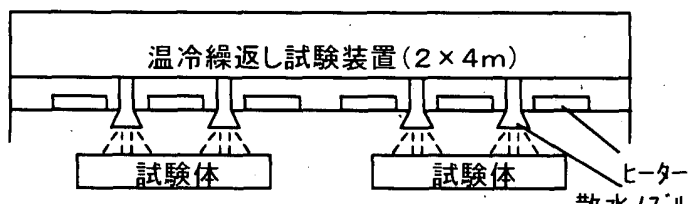

図ー1 温冷繰返し試験(熱サイクル試験)概略図

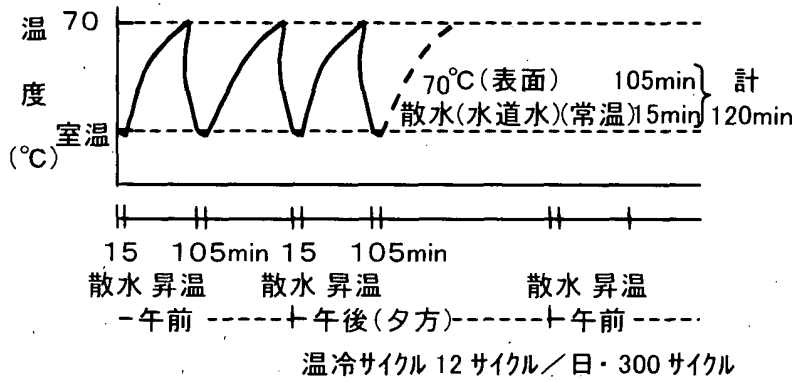

図ー2 温冷サイクル図
水して15 min で空湍まで冷却する。これを1 サイクルと設 定して、300 サイクルまで試験を尖施した。図一 1 に湍冷 繰这し試験（熱サイクル試験）装置の概略図を、また、図一 2には洫冷サイクルを示す。

\section{4）凍結融解後の接着強さ試験}

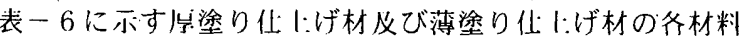
について、4.6 と闰様に作製した試験休を28d乾煰善生し た後、二分割して四侧向及び底们部をエポキシ樹脂でシール し、 $5 \mathrm{~d}$ 乾燥羑生した。その後、外装用については 4.4 に示 す侧样のわ法で、はっ水剂の塗布を行った。条試験体につい て、JISA 143.5 (建築州外壁材料の耐凁害性試験力法（凁 絬融解法)）に準じて試験を行った。齐試験休について48h 水中浸漬後、直ちに図- 3 に示すように、 $-20{ }^{\circ} \mathrm{C} 2 \mathrm{~h}$ 父中 谏結、1 $0{ }^{\circ} \mathrm{C} 2 \cdot \mathrm{h}$ 水中融解を 1 サイクルとし、10 サイクル、 30 サイクル、 50 サイクル、100サイクルの齐サイクル 行った垍後の吸水などに伴う質量変化及び齐サイクルごとの 㑕着強さの変化を、4.6 1) 標準時接着強さ試験方法と问 様の方法で測定した。なお、10 0 サイクル以降も、質量変 化を中心に、試験体の状況を観察しながら凍結融解試験を継 続し、300サイクルまで試験を尖施した。1 00 サイクル 以降の接着強さ試験についても、試験体の状況に吣じ接着強 さ試験が川能と判断されたものについて夹施した。なお、比 較として、薄塗り訨、将材については、内装开のものについ ても闹様の試験を行った。図ー 3 に本試験における凁結融解 サイクルをホす。

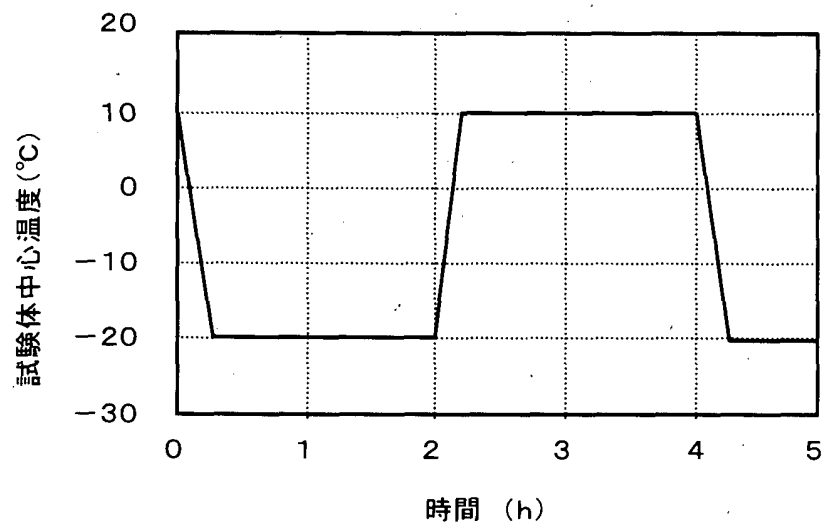

図ー3 涷結融解サイクル

\section{5）屋外暴露後の接着強さ試験}

表一6に示す耑塗り仩はげ材B（外装开）、薄塗り仩はげ材 C（外装成及び内装用）及びD（外装成及び内装为）につい て、4.6 と闰様に作製した試験休を $28 \mathrm{~d}$ 乾哑養生した後、

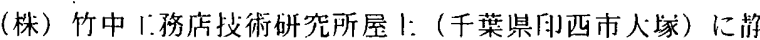
置し、屋外暴露試験を閶始した。

1 か月、3 月、 6 か月、12 か月及び 24 か月ごとに試 験体を空内に取り巡み、 $7 \mathrm{~d}$ 乾燥羑生したのち、4，6 1) 梆準時接着強さ試験方法と间様の力法で接着強さ試験を失施 し、その経時変化について検封した。 


\section{7 凍結蛋解に対する抵抗性試棦}

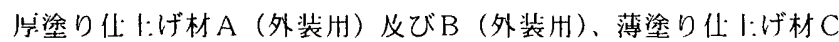
（外装筡及び内装州）反びD（外装装及び内装州）について、吸水 試験後の試験体（寸法、 $40 \times 40 \times 160 \mathrm{~mm}$ ）を为いて、JIS A 1435 に烧定する父仲凁絬水中融解法に準じて試験を行った。0、 $30 、 60 ， 100 ２ 00$ 义び300サイクルごとに、試験休の 質荲変化及び動弾性倸数の測定を行い、写具撮影を行った。

\section{5. 試険結果及び考察}

\section{1 基本物性}

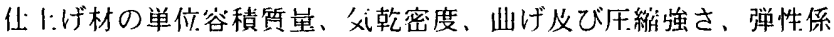
数、熟伝導率、吸水率及び冬試験条件トの接着強さを一筧表にまと めて表一 7 に示す。まず、強さについてみてみると、岁塗り仩はげ 材 $\mathrm{A}$ 及び $\mathrm{B}$ 、薄塗り仕 1:げ材 $\mathrm{C}$ 及びDは、一般のセメントモルタル 系仩、げ材に比べて維強さは小さいが、仩、将材としては十分な 強さを有しており、特に問題はない。今体的には、いずれの材料も、 仕、げ材として十分満足する值といえる。また、弾性係数について

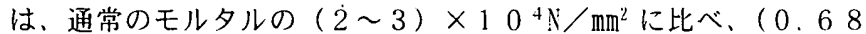

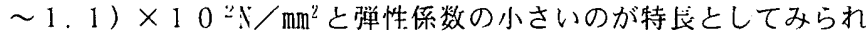
る。また、いずれも父乾密度が $0.8 \sim 1.2 \mathrm{~g} / \mathrm{cm}^{3}$ と極めて軽量で あると共に、熱伝導率も0.17〜0.30 W/mK と小さく、断熱性 に優㧈ている。このように、この仩、将材は、従来のセメントモル タル系の仕は:材にはみられなかった特长を不している。これら軽 量性と断熱性の関倸については、有機と無機のマイクロバルーンの バランス瓜い材料满成に起内するものと判断される。また、吸水率 については、はっ水剤の処理により人幅に改善される。

表一7 仕上げ材の基本物性值

\begin{tabular}{|c|c|c|c|c|}
\hline 試験項甘 & $\begin{array}{c}\text { 岗塗り } \\
\text { 仕ト:げ材 } \mathrm{A}\end{array}$ & $\begin{array}{c}\text { 㟜塗り } \\
\text { 仕:げ材 } \mathrm{B}\end{array}$ & \begin{tabular}{|c|} 
薄塗り \\
仩: $\mid$ げ材 C
\end{tabular} & 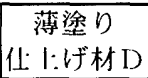 \\
\hline 単位谷積質量 $(\mathrm{kg} / \mathrm{l})$ & 1.21 & 1.20 & 1.25 & 1.33 \\
\hline 父i乾密度 $\left(\mathrm{g} / \mathrm{cm}^{3}\right)$ & 1.10 & 1.08 & 0.86 & 1.20 \\
\hline 剀げ強さ $\left(\mathrm{N} / \mathrm{mm}^{2}\right)$ & 1.36 & 1.49 & 1.28 & 1.35 \\
\hline 厈䋺強さ $\left(\mathrm{N} / \mathrm{mm}^{2}\right)$ & 2.49 & 2.72 & 2.16 & 2.56 \\
\hline 弾性係数 $\left(\times 10^{2} \mathrm{~N} / \mathrm{mm}^{2}\right)$ & 1.10 & 1.10 & 0.68 & 1. 10 \\
\hline 熱伝導率 $(\mathrm{W} / \mathrm{mK})$ & 0.30 & 0.26 & 0.17 & 0.30 \\
\hline 吸水率 (vol\%) & 1.3 & 1.3 & $\begin{array}{c}2.3 \\
(23.4)\end{array}$ & $\begin{array}{c}2.1 \\
(20.4)\end{array}$ \\
\hline
\end{tabular}

注）（）は、内装用（はっ水剤塗布なし）

\section{2 接着強さ及び接着酎久性}

\section{1）摽準時接着強さ}

表ー8には、仩は:げ材の標準時挍着強さを示す。优は:げ材 の接着強さは、JISA 6909 （建築州仕1:塗材）に烧定す

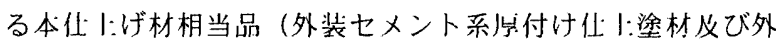
装セメント系薄付け仩!塗材）の基準值を十分満足している。 接着性が良好であるのは、仩に:げ材に含まれるポリマーの効 果によるものと觉えられる。

2）水中浸漬後の接着強さ

表一8には、仕は:げ材の水中浸漬後の接着強さを示す。薄

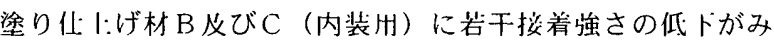
られるが、外装用のものにつては、JISA 6909 に烧定す
る試験法に比べて戦しい試験にもかかわらず、その基準值 を十分湍足している。接着強さ試験後の試験体の破壊状況は ほとんど仕、:げ材白怵の凝炛破壊であった。

表一8 壮上げ材の接着強さ

\begin{tabular}{|c|c|c|c|c|}
\hline 試験項甘 & $\begin{array}{c}\text { 管塗り } \\
\text { 仩:げ材 }\end{array}$ & $\begin{array}{c}\text { 岗塗り } \\
\text { 仩!:げ材 } \mathrm{B}\end{array}$ & $\begin{array}{c}\text { 薄染り } \\
\text { 仩: } 1: \text { げ材 C } \\
\end{array}$ & $\begin{array}{c}\text { 薄塗り } \\
\text { 仩: } 1 \text { :゙材 D }\end{array}$ \\
\hline $\begin{array}{l}\text { 槽準時 } \\
\left(\mathrm{N} / \mathrm{mm}^{2}\right)\end{array}$ & 0.74 & 0.69 & 0.67 & 0.93 \\
\hline $\begin{array}{c}\text { 水中浸漬後 } \\
\left(\mathrm{N} / \mathrm{mm}^{2}\right)\end{array}$ & 0.60 & 0.59 & $\begin{array}{c}0.61 \\
(0.48)\end{array}$ & $\begin{array}{c}0.82 \\
(0.48)\end{array}$ \\
\hline
\end{tabular}

注）（）は、内装州（はっ水殽塗布なし）

\section{3）温冷繰返し試験（熱サイクル試験）}

洫冷繰这し試験（熱サイクル試験）における卆サイクル試

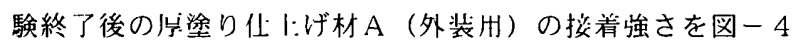
にホす。この図にみられるように、洫汾繰这し試験（熟サイ クル試験）のサイクル数の増加に伴い、仕、!壮材の接着強さ は、初期値の $0.7 \mathrm{Y} / \mathrm{mm}^{2}$ よりむしろ順次增加する优何にある。 これは、仕、げ材の弾性倸数が小さいことによって、仩にげ 材とコンクリートト地との接着界响における熱心力の紘和効 果が期待できるためと、散水による水分の供給前びに加熱に よる水和反心の進行に基づくものと学えられる。また、接着 強さ試験後の試験怵の破壊状況は、ほとんど仩、げ材白体の 凝集破垻であった。以ト:の結果、洫泠繰这しや乾湿繰这しな

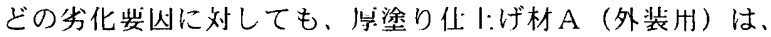

極めて優れた接着耐久性を有しているといえる。

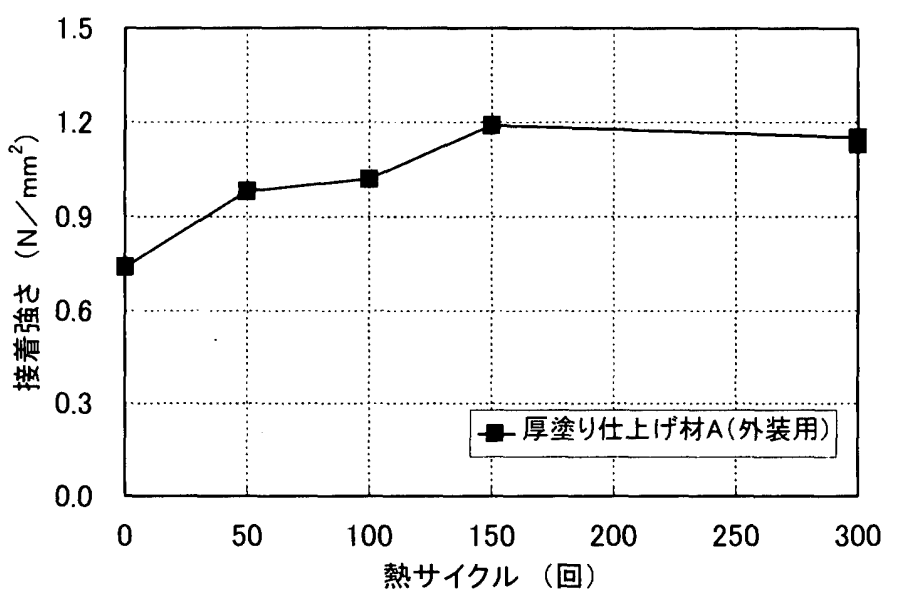

図-4 温冷繰返し(熱サイクル)試験後の接着強さ

\section{4) 凍結融解後の接着強さ}

図ー 5 及び図 -6 に凁結融解試験開始後の齐サイクルにお ける質荲変化率及び按着強さを、また、図一 7 には凁絬陆解

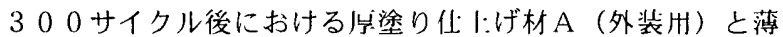

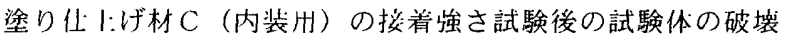

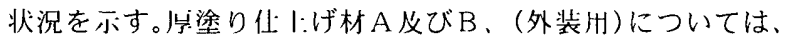
質量変化も小さく、合わせて掞着強さの低トも小さい。凁絬 融解 300 サイクルに達しても、仙ら外観変化も認められず、 
谏結融解に刘する抵抗性に極めて優㧈ていることが確認でき る。薄塗り仩・げ材については、凁結融解サイクル数の増加 に伴う吸水による質量堌加がいずれも著しいが、凁繀融解 5 0〜 100 サイクルにかけてコンクリートト地が凁害を受け てひび割れの発生の見られるものが增えてきたことなどから、 これらの進行に起因するものと考えられる。しかしながら、 表淌の仩、げ材の接着強さについては、コンクリートト地の 凁害によるひび制れの発生にもかかわらず人きな低トは見ら れず、仓休的に良好であった。なお、凍結誳解サイクルの進 行に伴い、コンクリートド地が凁害を受けて損傷したため、 損仵の程度によって薄塗り仩はげ材D（内装㕫）については

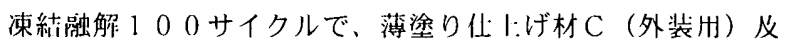
び薄塗り仩トげ材口（外装州）については凍結融解１８０サ イクルで試験を中止した。凁害によるド地コンクリートの損 傷の小さかった薄塗り仩!:げ材 C (内装开) だけは、凁結融 解 300 サイクルまで試験を継続し、接着強さの低ドのない ことを確認した。

以に:のように、試製仕 は:げ材は、コンクリートド地の凁害 にもかかわらず、ほとんど凁害を受けないほど凁結唰解に刘 する抵抗性に優扎ているその理山としては、ポリマーディ

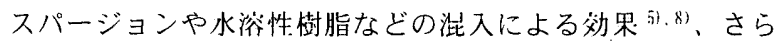

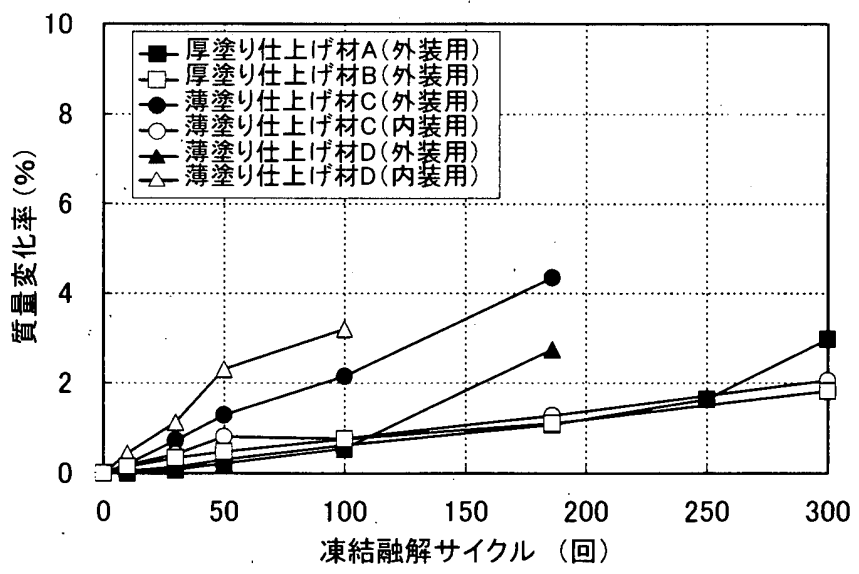

図－5 接着耐久性試験における凍結融解サイクルに伴う質量変化率

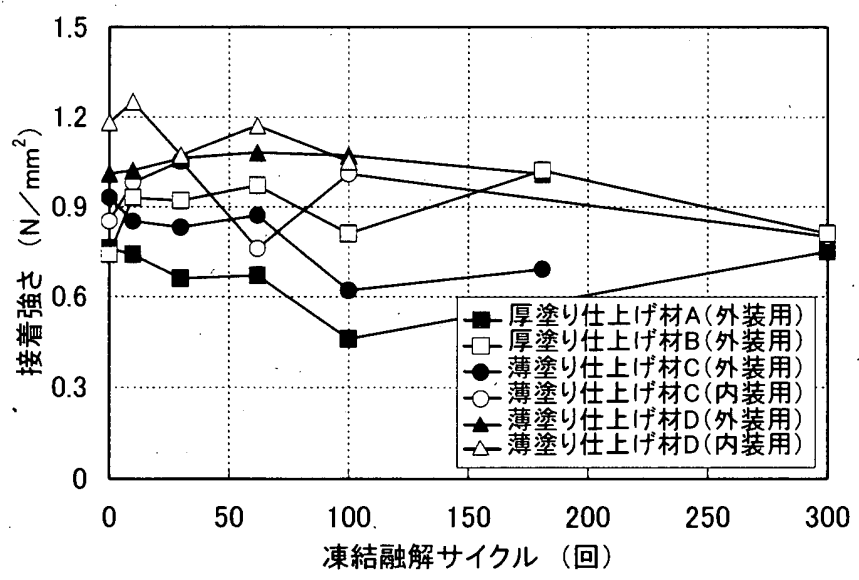

図-6 凍結融解試験後の接着強さ

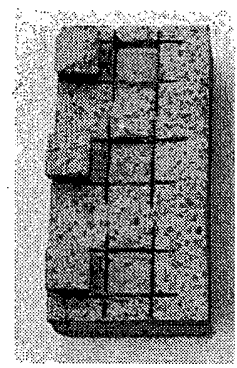

厚塗り仕上げ材 $\mathrm{A}$ (外装用)

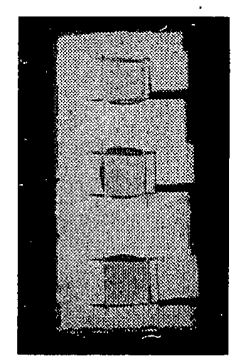

薄塗り仕上げ材C (内装用)

\section{図ー7300サイクルの凍結融解試験における 接着強さ試験体の破壊状況}

には変形能力が人きい軽量骨材としてのポリ盐化ビニリデン 発泡体の緩和㤎果なども加わったバランスの良い材料構成に よるものと推察される。

\section{5）屋外暴露後の接着強さ}

図一8に、柦塗り仕!:げ材B（外装时）及び薄塗り仕にげ 材 C（外装装及び内装开）及びD（外装为及び内装装）の屋 外暴露 2 年甘までの接着強さの経時変化を示す。いずれの材 料についても、㑕着強さの低卜はみられず、一連の空内実験

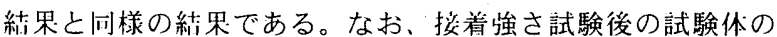
破壊状況は、いずれも仕!:げ材白体の凝集破壊であった。

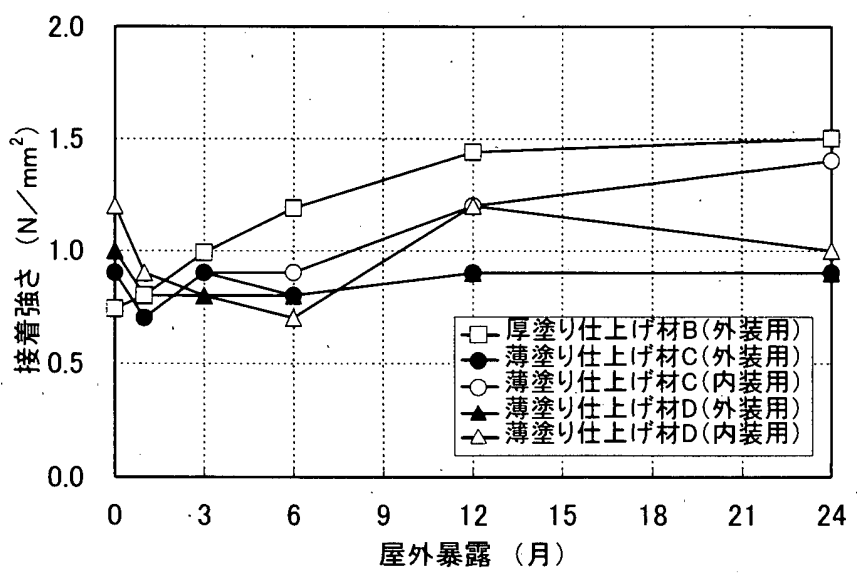

図-8 屋外暴露試験後の接着強さ

\section{3 凍結融解に対する抵抗性試験}

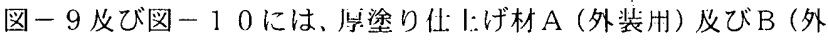

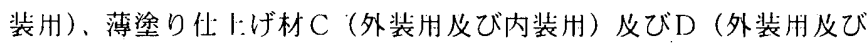
内装州）の凁結融解３００サイクルまでの質量変化及び相刘動弹性. 倸数の変化を示す。薄塗り仩 1:げ材 B (外装用) に相刘動弾性倸数 の低トが若干認められるものの、60\%をド网ることはなく、その

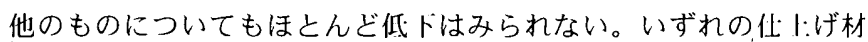
についでも外観変化及び質堇変化はほとんどみられず、凁絬瀜解に 刘する抵抗性に極めて優れていることが確認できる。また、はっ水

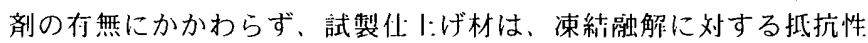
に非常に優れている。この理山は、5.24)と间様と觉えられる。 


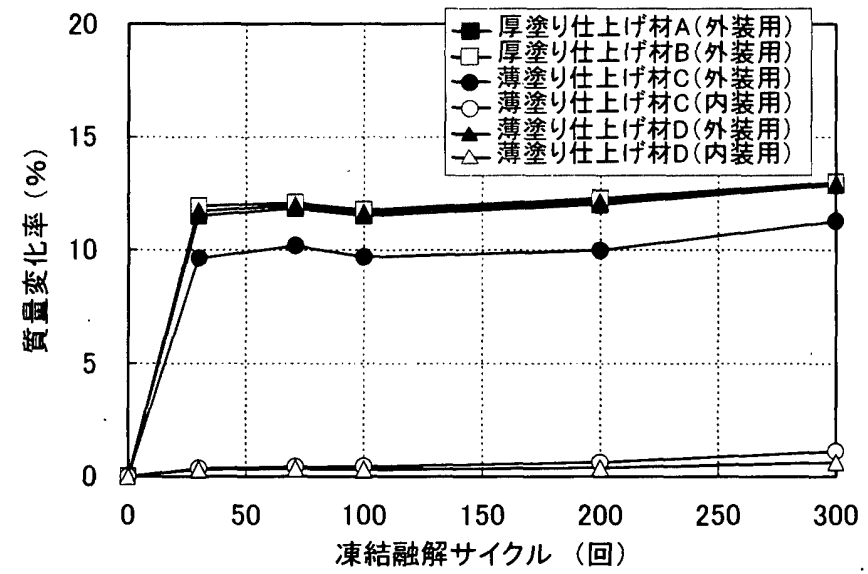

图-9 凍結融解サイクルに伴う質量変化率

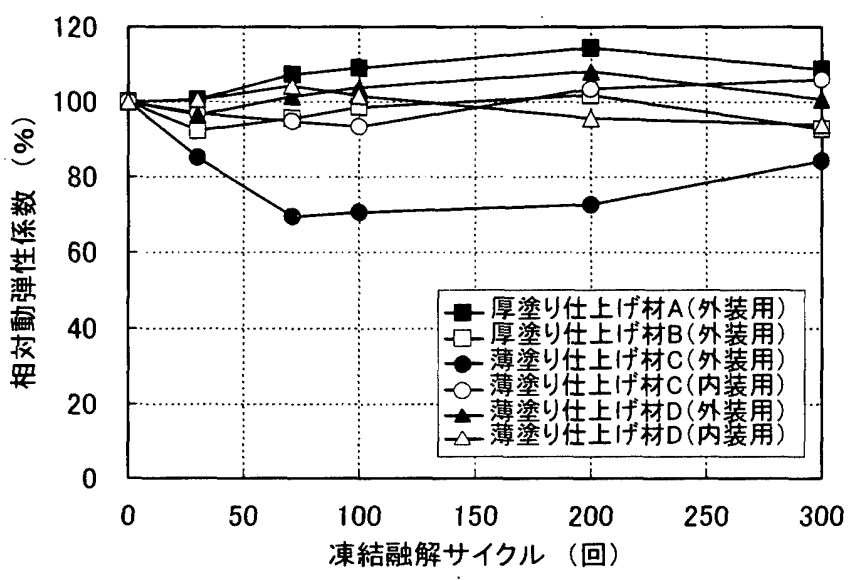

図ー10 凍結融解サイクルに伴う相対動弾性係数の变化

\section{6. まとめ}

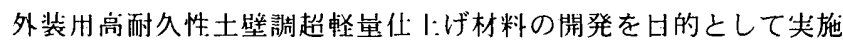
した、以I:の試験結果を取りまとめると、次のとおりである。

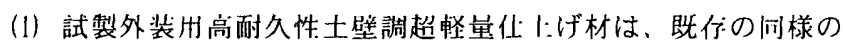

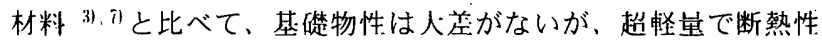
に優れている。

（2）試製外装出高耐久性土壁調超軖量仩:げ材は、既伃の问様の 材料 31.7と比べて、その凁結融解に対する抵抗性，及び接着耐久 性が相当に優れている。

（3）試製外装筡高耐久性土壁調超軽量仩・げ材の以ト:述べたよう な卓越した特性は、この材料が色ポルトランドセメントと無 機及び有機質マイクロバルーンをベースとし、これにポリマー ディスパージョンや水浴性樹脂などを混和した一㮔のポリマー セメントモルタルを、炭素䋐維で補強して製迠することに山来 するものと考えられる。従って、本研究で開発した外装用高耐 久性土壁調超軽堊化・:げ材は、寒冷地における使而が川能とな り、しかも湿式施 I:の外装卅仕に:げ材として、相当に苛酷な環 境ドでも使州できるものと推察される。

\section{考文胡}

1) Y. Shinozaki:Development and Application Research on Multifunctional Super Lightweight Motar -Apnlication to Thermal Insulation and Condensation-Proof Construction Method-. Proceedings of the Z2nd International SAMPE Technical Conference. Boston. USA. pp. 986 $\sim 997.1990 .11$

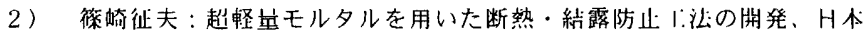
建築学会技術報告集 第 2 万、, p. 20〜23.1996.3

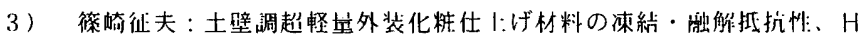
本建築学会大会（中同）学術满演被慨集 A-1, pp. 1025-1026,1999.9

4）錚田英治、小内一之、南野利㚔：硬化セメントベーストの䧒害と縕孔

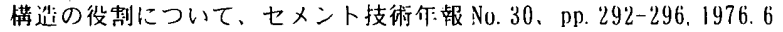

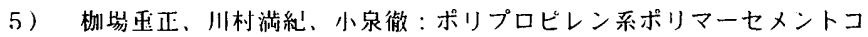
ンクリートの珯性質、セメント技術尔: 報 No. 32、pp. 312-319.1978. 5

6) 策崎征夫：超軽皿セメントモルタルの開発と住 I: 材料への心用、HA 处築仕 1 :学会大会学術满演会破究発衣諭文集、pp. 229-232.1996.9

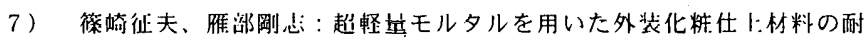
久性: 、本建築仕 I: 学会大会学術满演会砄究発表諭文集、 pp. $57-60,1997.10$

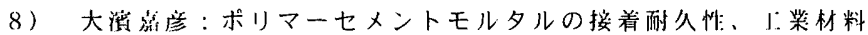
Vol27, №. 7, pp. 51-54, 1979. 7

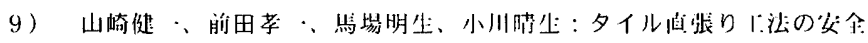
性に関する研究（その4モデル武験体の熟泠繰り这しによるムーブメ

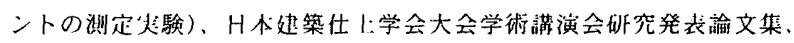
pp. $213-216,1993.9$

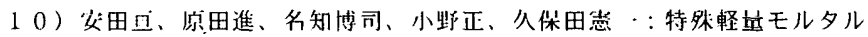
を用いたタイル任张り1:汒の闆発、H本建築学会大会（中国）学術講 演梗概集 A-1、pp1051-1052,1999.9

(2002年 7 月 10 日原稿受理, 2002 年10月15日採用決定) 